\title{
Unusual Presentation of Glomus Tumor in a Child
}

\author{
Sudhir Singh, ${ }^{*}$ JD Rawat, Digamber Chaubey, Gurmeet Singh
}

Department of Pediatric Surgery, King George's Medical University, Lucknow, India

\begin{abstract}
Correspondence*: Dr Sudhir Singh, Assistant Professor, Department of Pediatric Surgery, King George's Medical University (KGMU), Lucknow, India.

E-mail: drsudhir_singh25@yahoo.in

Submitted: 03-05-2017

Conflict of Interest: None

(C) 2017, Singh et al,

Accepted: 18-06-2017

Source of Support: Nil

This is an open-access article distributed under the terms of the Creative Commons Attribution License, which permits unrestricted use, distribution, and reproduction in any medium, provided the original work is properly cited.
\end{abstract}

\section{DEAR SIR}

A 6-year-old girl presented with a large $(15 \times 10 \times 8-\mathrm{cm})$ mass over left thumb for two years associated with severe pain (Fig.1A,B). She is resident of a remote area where medical facilities were not available. On examination, the whole left thumb is covered in mushroom fashion by fleshy mass sparing its base. $X$ ray of hand showed left thumb soft tissue mass sparing bone (Fig.1C). Incisional biopsy confirmed it a glomus tumor. Patient was managed with thumb amputation due to extensive involvement (Fig.1D). Histopathology was consistent with round glomus cells with a sharply punched out rounded nucleus (Fig.1E).

Glomus tumor was first described by Wood in 1821 and the characteristic histological description was given by Masson [1]. These relatively rare tumors account for $5.5 \%$ of nail unit tumors [2]. Clinical features were described as a triad of temperature sensitivity, severe pain and localized tenderness in $63-100 \%$ of the patients [1]. They are mostly located in the subungual region but may occur less frequently at extra digital sites. Although generally benign, glomus tumors can also exhibit malignant and metastatic potential in rare cases [3]. These lesions are managed by surgical excision. Our case is unique as such a large tumor in a pediatric patient $(15 \times 10 \times 8 \mathrm{~cm}$ and weighing $400 \mathrm{gm}$ ) has not been reported previously to the best of author's knowledge. The present report highlights the significance of early access to medical treatment as delay has led to amputation in a benign condition.

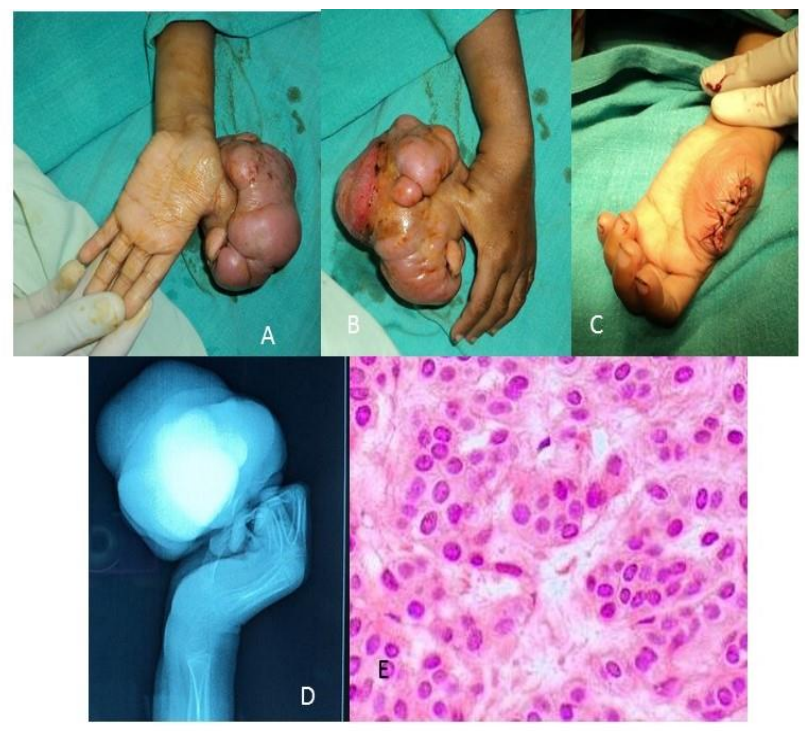

Figure 1: $A$ and $B$ showing the mass involving the whole left thumb, $C$ After surgical removal, D -Plan $X$ ray of left hand showing soft tissue mass and E-histology showing round glomus cell with a sharply punched out rounded nucleus.

Consent: Authors have submitted signed consent form from legal guardians of the patient for use of clinical material in this manuscript. The Consent form is available with Editorial office.

Authors' Contribution: All authors contributed equally in concept, literature review, and drafting of the manuscript and approved the final version of this manuscript. 


\section{REFERENCES}

1. Domínguez-Cherit J, Chanussot-Deprez $\mathrm{C}$, Maria-Sarti $\mathrm{H}$, Fonte-Avalos V, Vega-Memije E, Luis-Montoya P. Nail unit tumors: A study of 234 patients in the dermatology department of the "Dr.ManuelGea González" General Hospital in Mexico City. Dermatol Surg. 2008; 34:1363-71.
2. Heys SD, Brittenden J, Atkinson P, Eremin O. Glomus tumour: An analysis of 43 patients and review of the literature. Br J Surg. 1992; 79:345-7.

3. De Chiara A, Apice G, Mori S. Malignant glomus tumour: a case report and review of the literature. Sarcoma. 2003; 2:87-91. 